\begin{abstract}
Informal observation by University of the West Indies (UWI) Mona librarians and anecdotal evidence from UWI faculty suggested that information literacy skills among students at the UWI Mona are inadequate for university level. Results of an informal survey of IL in select high school libraries in Jamaica indicated school IL programmes were not preparing students adequately. Therefore, the authors propose forging alliances between the University Mona Library and high school libraries to improve IL programmes in the high schools. The paper draws on three recent successful cases of collaboration between the UWI Mona library and high schools. It ends with some recommendations.
\end{abstract}

Since 2001, incoming students at the University of the West Indies (UWI) at Mona ${ }^{1}$ have been exposed to information literacy (IL) skills through programmes run by the Library's teaching section, the Mona Information Literacy Unit (MILU). However, even after such exposure, students' retention and application of these skills seem to be very low, an assessment based on informal observation by librarians at the reference desk and in the catalogue hall, and on anecdotal evidence from lecturers on students' information literacy skills.

Supporting evidence came from informal research carried out among the students themselves. Approximately 400 new undergraduates completed a short questionnaire during the Library's component of the University's 2001 and 2002 orientation sessions. Analysis of a haphazard sample of 253 of these questionnaires indicated freshmen's limited exposure to the information-finding tools used at the university level. Few respondents said they knew how to search a card $(35 \%)$ or online (15\%) catalogue, or used search engines to find information $(41 \%){ }^{2}$ While these findings do not necessarily constitute a measure of students' IL competencies, they do point to the size of the gap that needs to be closed at the university level.

Recognising the needs of university undergraduates as well as the constraints and challenges school librarians face, the authors propose a forging of IL alliances between the UWI Library and high school libraries. This paper draws on three recent cases of collaboration between the UWI Mona Library and high schools that could be expanded into such alliances. The paper can be divided into two broad sections. The first examines the problem of inadequate IL skills among incoming students; the latter discusses in some detail the collaboration. The paper ends with some recommendations.

\title{
The Role Of The Library In IL
}

In addressing the need for UWI graduates to respond to a constantly changing environment, the Administration recently advocated an expanded programme of teaching and a multi-disciplinary approach to research. According to the Principal of Mona: "The campus will emphasize sound undergraduate education...to produce graduates capable of thinking, researching material, analysis, integrating knowledge and coherent expression of ideas" (Mona Campus Development Plan 1999-2000, p. 6).

Although not explicitly stated as IL competencies, the attributes included in the University's vision are similar to the competencies identified by the Association of College and Research Libraries (ACRL) as necessary for students in higher education institutions. The ACRL Standards make it clear that these IL competencies become "increasingly 
important in the contemporary environment of rapid technological change and proliferating information sources." (2000, p.2) UWI's vision is also close to that of the American Library Association on the role of IL:

Information Literacy forms the basis for lifelong learning. It is common to all disciplines, to all learning environments, and to all levels of education. It enables learners to master content and extend their investigations, become more self-directed and assume greater control over their own learning.

(Information Literacy Standards, 2000, p.2)

To develop graduates with the attributes envisioned by the UWI Administration, the Mona Information Literacy Unit (MILU) was set up in January 2001 as a sub-section of the Library's Loan and Reference Section. ${ }^{3}$ It draws on the assistance of Reference Librarians, a specially trained group of librarians as Internet Trainers, as well as other librarians for very large classes.

Focusing on Information Literacy as 'the ability to locate, evaluate, and effectively use information,' the Unit aims to assist in developing students' higher order critical skills and independent learning by

- Emphasis on critical research skills in all teaching modules;

- Setting of objectives, standards and outcomes for student learning;

- Inclusion of all types of information sources and formats (cf. the Library's print resources) in the information seeking and evaluative process;

- Promotion of IL to Faculty and Administration, and in particular, faculty collaboration with the Library and the integration of skills within the curriculum;

- Developing the teaching skills of librarians. To this end, a number of in-house workshops have been conducted, and three librarians have attended the ACRL Institute for Information Literacy Immersion Programme.

Currently the IL Programme includes:

- A module in two University Foundation Courses, 'Writing for Academic Purposes' (FD10A) and 'Language, Exposition and Argument' (UC120). In the last academic year 2001-2002, over 1500 students were reached via these modules;

- Collaborative sessions/modules within subject courses at the request of Faculty, thus reaching a wide range of students, including those in graduate programmes;

- Open sessions on 'Research strategies on the Internet', 'Using the OPAC', and 'Using online databases'.

Innovative teaching methods have been employed, e.g., a skit on "The Information Literate Student" produced initially for a session promoting IL to Faculty. ${ }^{4}$ This presentation, depicting competencies of the information literate student, was subsequently captured and used in a number of PowerPoint Slide Shows. It was included, too, as a live presentation in the UC120 lecture this academic year. A video, e-literate? (UCLA and Pacific Bell, 2000), has also been used to stress evaluation of information sources. There has been an emphasis on pedagogy, especially connecting with students through question and answer interaction, and encouraging independent learning through hands-on exercises.

\section{The Problem}

It is clear that the Library's IL modules are not intended to be introductory, but to build on the knowledge the Library assumes students have brought to UWI. As implied, the Library's assumptions are unfounded. Both Faculty and librarians have indicated that, even after participating in the IL modules, students continue to display an inability to fully assimilate the higher order skills that were taught.

During Library-Faculty discussions at the start of the last two academic years (2001/2 and 2002/3) faculty members expressed frustration with the inability of students to demonstrate both a critical approach to learning and research and basic information skills to operate within the university environment. In September 2001, the views of 150 Faculty members were sought in an informal survey at the Library's Annual Faculty Lunch-Time Orientation Sessions. Faculty were given a very short 'questionnaire' that was essentially a sheet with two statements, "I wish my students would..." and "I wish my students would not..." (Appendix A) 
The range of responses is detailed in Table 1, but it was clear that, according to their lecturers, students were not internalising nor transferring the information skills to which the Library sessions had exposed them.

Table 1. Comments from UWI faculty on students' competencies

Qualities of Ideal Student

"I wish my students would..."

Find reference books

Read History Today and other current journals

Stay curious

Attend lectures and tutorials

Read the material assigned

Be able to apply their own initiative to learning

Have an inquiring mind

Have readiness for class

Have the willingness to do extra work to improve performance

Read many sources

Make use of subject catalogue to find alternate texts

Seek education and not certification

Improve in their use of English

Challenge the tutors more with alternative ideas

Use electronic resources in writing their papers

Read independently

Be better prepared for their exams

Critically analyze the sources

Use relevant information

Document or cite sources properly

Think, read and write critically

Be more articulate in oral and written discourse

Complete assignments on time

Be proactive in areas of research

Participate in courses

ㄱ. Think for themselves, keep and use their common sense

Use open shelves in library

Consult bibliographies in all forms

$\square \quad$ Read foreign newspapers

Concerns about students

"I wish my students would not..."

Plagiarize

Abuse the resources of the library

Make noise inside and outside of the library

Destroy books and journals

Hide, misplace, steal and keep books

Mark books

Accept written material as gospel

De-contextualize what they read

Regurgitate from lectures and books

Fail to organize written work properly

Be afraid to speak their minds and ask questions

Rely on the tutors and lecturers to supply all the information needed

Delay in preparation

Copy large chunks of data without understanding it

Use only old and outdated sources for research

Detest reading, researching and analyzing

Lack preparation for tutorials

Keep asking which is the best text

Buy course required texts only

Purchase dictionaries only

Hand write essays

Think purely in terms of passing exams

Write like a Gleaner journalist 


\section{Comments from UWI Faculty on students competencies}

The views of Faculty were corroborated by the experience of Reference and Instruction Librarians who report that many students displayed dependence on a very few sources of information, inability to use a catalogue effectively to identify material on a topic, and often were incapable of expressing an information need. In some cases, this was evident even after IL sessions. Three major reasons have been proffered for this state of affairs:

- Too many new concepts are being taught in too short a time;

- There is little opportunity for reinforcement for the majority of students who were taught in one-shot sessions;

- Most incoming UWI students have had little prior exposure to IL skills.

The data from the 'warming up' questionnaire (Appendix B) referred to above support the contention that students' prior exposure to using a library or to research skills is limited. This view is not without support elsewhere. Elspeth Goodin, researching a number of libraries in the United States, comments that "Discussions with college librarians involved with library instruction programs indicate that a significant number of students have been entering college unprepared to function efficiently and effectively in an academic library." (1991, p.33). Describing the US environment also, Dickenson states that:

even those students not crippled in other ways by their preparatory education are, almost without exception, totally innocent of how a library works and do not have even a vague idea of how to set about finding information they need or want when they arrive at college or university (1981, p.853).

According to him, if students were properly instructed in high schools academic librarians could move beyond remedial work to reinforcing basic skills and moving on to higher order ones.

It is unlikely that, in the near future, the amount of time allowed for direct II training at UWI will be increased. MILU will have to concentrate on dealing with the higher order skills. Consequently, a large part of the solution to the problem rests with the high schools and so it becomes imperative that UWI librarians understand the situation in Jamaican/Caribbean high schools as a necessary preliminary step. Cahoy supports this: "It is important to become familiar with the skills with which students are entering college, and there's no better place for academic librarians to start learning about students' potential needs than at the local high school and its library." (2002, p.4).

\section{State of High School Libraries}

In Jamaica, the Schools Library Network (SLN), a division of the public library system, has responsibility for the libraries of most of the island's high schools. Some of the services offered by SLN are centralized acquisition, staff training in basic library science as well as visits to monitor progress and offer advice. (Shelley Robinson, 2000). However, SLN's responsibility does not extend to approximately 50 technical high and traditional grammar schools, some of which are the top feeder schools for UWI Mona. Shelley Robinson indicated that there were numerous challenges and constraints within the Jamaican school system and, within that of the school library, that affected the level and quality of library instruction. These include:

- No formal government policy for the operation, staffing and funding of the school library;

- Unclear policy on the role and function of the school librarian;

- Not enough qualified library staff;

- Lack of available computer facilities in schools;

- Uneven library provisions, space, material and inadequate budget.

Although a few changes have occurred in the last two years, these have not been significant and the trends continue. (Jamaica Library Service, SLN Region 1 Report, December 2002.) 
In respect of the library instruction given in the schools, Shelley Robinson also found similar challenges:

- No formal information skills syllabus; thus, content is ad-hoc and arbitrary: "...the Ministry of Education does not have a formal information skills syllabus so librarians are left to fashion their own, so there is no uniformity or consistency in what is taught and how" (2000, p.8);

- Classes are taught in isolation from the curriculum;

- Emphasis is on library skills in the traditional mode: i.e., on skills in locating and using print resources.

A survey of 15 selected high schools ${ }^{5}$ conducted by the authors over one week in March 2003 suggested that the situation remained substantially the same as in 2000. The telephone survey included 8 traditional grammar schools, 1 technical high and 6 newer (upgraded secondary) high schools. Calls were made to librarians identified via the mailing list of the Schools Section of the Library and Information Association of Jamaica (LIAJA). More schools had been identified for polling, but it was impossible to reach some of the librarians, as there was either no telephone in the library or librarians were involved in heavy schedules of subject teaching. Despite the obvious weaknesses in the survey, however, the findings seem to corroborate the earlier findings of Shelley Robinson. On the plus side:

- Library/information skills are taught in all but one of the schools surveyed;

- Zeal and interest were expressed by most teacher/librarians about teaching information skills;

- Most librarians surveyed were qualified and had additional training in teaching information skills, chiefly through workshops and seminars conducted by the Schools Section of LIAJA.

\section{On the negative side:}

- Formal teaching of library/information skills is done only at the lower levels, i.e. between grades 7 and 9;

- Most librarians cover traditional skills (Table 3);

- No two librarians surveyed worked from the same curriculum;

- There was little collaboration between subject teachers and school librarians on integrating competencies within the curriculum. [Three librarians indicated that they assisted with identifying teaching materials for classes, and a few of those who have attended IL training indicated they integrated examples from subject classes in teaching IL skills]

On the issue of collaboration between teachers and librarians, Senator (1995) feels that "It is more difficult to collaborate in high schools because of the way schedules are set, the autonomy of subject area departments, and how high school teachers see their content defined." (as cited in Bishop \& Larimer,1999, Literacy Collaboration section 3). In the Jamaican context, Shelley Robinson (2000) also points out that, because teachers themselves lack information skills, they tend to resist integrating IL programmes into their classes.

Yet the integration of information skills is stressed by writers such as Benjamin Bloom: "Our general understanding of learning theory would seem to indicate that knowledge which is organized and related is better learned and retained than knowledge which is specific and isolated." (as cited in Goodin, 1991, p.33). Dianne Kester, in more specific terms, says that

High school library skills instruction appears to have little carry over or effect on students going on to college, with but a few exceptions. ... [L]ittle integration of library skills with course content appears to be taking place.... This may, in fact, explain the small carry over of library skills. If what is being taught is being done in isolation, research has for some time now shown this to be the least effective method of library instruction. (1994, p.17)

Transferable skills are skills taught in the context of real situations and collaboration, therefore, becomes essential for training in Information Literacy.

Further, the telephone discussions with librarians also revealed that in some high schools, students were not allowed access to the card/online catalogue as this was primarily for the librarian's use. In some of the schools, the library was relatively small and students could browse for themselves easily so the onus was on the librarian to locate any 
items not identified by browsing, becoming in the process the focal point for identifying and locating information. But as Beverly Renford (as cited in Goodin 1988, p17) has argued, students accustomed to browsing in small school libraries often have difficulties using a catalogue in another environment. At the Mona Library, many new students have an almost negative attitude to using the catalogue. Some do not grasp that the role of the librarian is to offer teaching in the use of the catalogue and not to direct them to specific sources on the shelves.

The most disturbing finding of the school survey was that teaching of library skills is concentrated at the lower grades. Equally disturbing was the fact that the librarians surveyed stated they had little or no control over this trend. The reasons include school policy, personnel and time constraints, as most operated solo and had other subject teaching assignments. Of those surveyed, only 4 schools offered formal library skills classes above grade 8 . [In one instance, classes for grade 9 students were primarily for remedial reading. In fact, 1 school offered library skills for one semester only in the grade 7 year]. There was no formal class teaching at the levels in which students would begin to do independent research at grades 10,11 and at $12 \& 13$ (the $6^{\text {th }}$ Form/Community College levels) prior to their entering university. All librarians surveyed agreed that students forget what is taught and that although they give one-to-one training at the higher levels there is need for structured instruction. What is lacking is what the AASL/ACRL Blue Print for Collaboration (2000) refers to as the seamless approach to teaching Information Literacy competencies, i.e. continuation of the teaching of these skills throughout the student's life.

According to the AASL/ACRL Blue Print for Collaboration, IL at the tertiary level, i.e. adopting of the Information Literacy Competency Standards for Higher Education, should be viewed as a continuation of the Information Literacy Standards for Student Learning used at the secondary level. The Blueprint advocates a 'seamless continuation' of the standards and recommends a "shared responsibility among academic and school librarians for information literacy." (2000, Background section 3 and Recommendations section C). It is agreed that skills taught at the college level should build on the experience of skills learned at the primary and secondary levels rather than starting anew. (Shelley Robinson, 2000 and Goodin, 1988).

Therefore, although it would seem that students in Jamaican High Schools are exposed to some library and information skills, the seamless approach is not evident as most get little or no exposure to research skills when needed, and especially for the last four years of school. This means that, by the time students graduate and are ready for university, they are unlikely to have mastered the basic skills. ${ }^{6}$

Yet Goodin (1988) found that high school students can learn information and research skills and transfer them to university. However, this teaching must include the senior levels of high school, i.e., when students are making other preparations for college/university life. She advocates the seamless approach, with the "high school librarian becoming a linking agent between the high school and college libraries" (p. iii) Collaboration with high schools then seems one of the best ways forward.

\section{Benefits of University-School Collaboration}

University-school partnerships are valuable (Young, 1999) and, under specific conditions, Information Literacy is one area that can benefit from such partnerships. "Instructional partnerships between university libraries and high school libraries can be successful when both partners are given the time and resources for developing collaborative projects with practical application"(Nichols, 1999,p.81). The AASL/ACRL Blueprint supports and advocates this kind of collaboration and the report of the Task Force includes examples of successful partnerships between schools and university libraries for IL. (2002).

The foundation for such collaboration exists at UWI. High school students as potential customers are welcomed on the Mona campus. Students and teachers are invited to the University's Annual Research Day when the departments (including the Library) showcase the work of students and staff (especially as these relate to the wider society), promoting the University as integral in the country's development. UWI's Career Week activities attract droves of high school students to the campus to explore the University's role as a gateway to a wide range of career choices. There have been longstanding relationships between schools and UWI departments, such as the Department of History in which Faculty plan workshops, seminars and sometimes field trips for high school teachers and students. 
The UWI Mona Library itself shares its Inter Library Loan (ILL) services with high school libraries at little or no cost. During the University's Research Day, the Library become a focal point for tours (mainly to high school students). At the 2003 Research Day, requests for library tours far outnumbered expectations. Ad-hoc orientation tours as well as requests from high schools for group/individual use of the Library are usually considered favourably. In particular, Grades 11-13 (Forms 5-6) students are allowed to use the Library for research projects by special arrangement.

\section{Information Literacy Collaboration}

What follows are descriptions of three collaborative ventures between the UWI Mona Library (through MILU) and high schools between 2002 and 2003.

\section{Case 1: Rural High School}

In November 2002, the Library responded to a request from the trained paraprofessional in charge of the library at Hampton School for Girls, a rural high school. Her Library Week Programme, focused on promoting reading, included presentations from well-known Jamaican storytellers and reading experts. Recognising the value of teaching critical information skills via reading, the staff member, through the school's Principal, requested that the Mona Library make a presentation on this topic.

\section{The Programme}

From the outset, we decided that the standards for the information literate student would provide the framework within which we would develop the presentation. We wanted to ensure that at the end of the sessions students were introduced to a few basic critical IL skills, in particular the skill of evaluating information, a higher order thinking skill often least used by UWI students.

To cater for the differing needs of students with a wide range of ages, (we were asked to make presentations to 840 upper and lower-school students), two separate presentations were prepared The overall objective of both was to introduce students to a number of evaluative techniques that may be used in reading information sources. The "critical reader' component, i.e. 'reading deeply,' was emphasised. Bishop (1999) points out that among the nine standards in Information Literacy for Student Learning, standard five emphasises literature: the student who is an independent learner is information literate and appreciates literature and other creative expressions of information. Since critical reading is essential at all levels and students may be taught information literacy competencies within this framework of literary appreciation, reading for pleasure was also included.

Since the group was fairly large and presumably incorporated various learning styles, we drew on a variety of teaching techniques: question and answer, story telling, dramatic presentation, and 'reflection time.' Audio-visual material and PowerPoint were used as tools.

\section{The Presentations}

1. "Beyond Words" to Grades 11-13 from Hampton as well as the neighbouring 'brother' high school, Munro College, included questions on what and why the students read. This provided the opportunity to introduce students to a range of other reading material such as reference books, periodicals, biography and fiction. Students then reflected on a questionnaire "How do I read." These simple yet provocative questions allowed for easy transition to discussing aspects of critical reading, in essence 'moving beyond words': reflecting on and asking questions of author, source, text and context. Following this, excerpts from two passages from the local newspaper, The Gleaner, were presented and then analysed for bias by the group. The video e-literate? was used to reinforce the need to evaluate information.

2. "Read for your life!" was targeted to Grades 7-9 students from Hampton. An interactive, somewhat easy going and lively session (students were younger and less inhibited), it included story telling, poetry reading and sharing of reading experiences among students and presenter. Yet it incorporated many of the competencies needed for the critical use of information and more specifically critical reading. So it included areas such as reading for pleasure and information, exploring a variety of reading material, asking questions and evaluating information sources (such as the two passages from the local newspaper.) 
After introducing students to broad areas of reading and critical skills, the presentations were 'topped' by a modified version of a skit, in which one of the presenters displayed props to support a script highlighting attributes of the 'information literate student' or the 'critical reader.' The skit presented the 'information literate student' as one who:

'Values inquiry and asks questions'

'Consults a variety of information sources'

'Analyses information in order to evaluate quality'

'Synthesizes new information with current understanding'

'Uses information responsibly and records sources used.'

A question and answer session allowed for feedback and opportunity to address issues from the students' perspective.

We also prepared and downloaded from the Internet handouts on aspects of critical reading for the library assistant to incorporate in her library/information sessions, as well as pointers for the students doing research. A gift of books, and a poster produced by the Commonwealth Library Association (entitled Read) were presented to the Principal. The library assistant requested follow-up assistance with additional material, including copies of the video on information literacy.

Students' response and feedback from teachers and library staff confirmed that this was a possible route to take for assisting high school students with developing information competencies. It seemed to us that students were eager and ready to learn, especially in a non-threatening, non-classroom environment, with the novelty of invited guests.

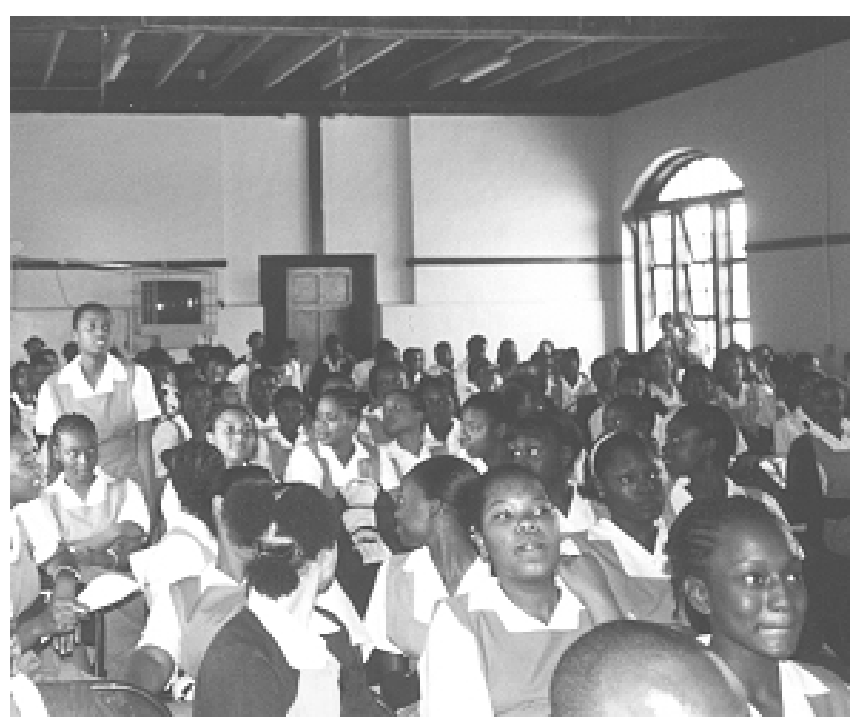

Figure 1

Hampton students in question and answer period during 'Read for your life!'

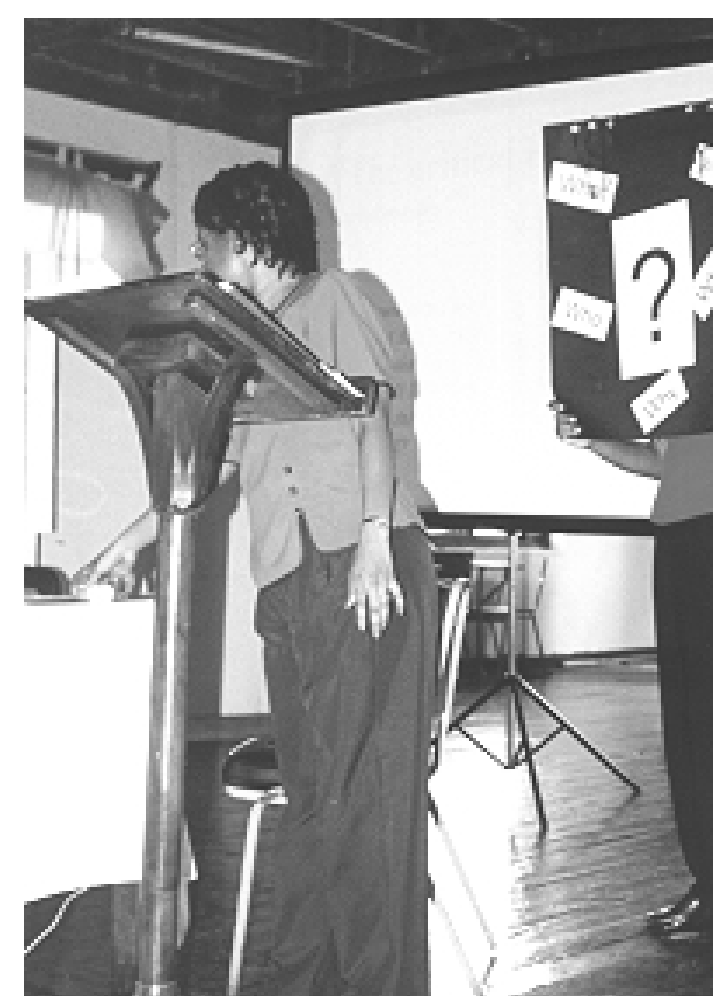

Figure 2.

Use of props highlighting the information literate student as one who 'values inquiry and asks questions' 


\section{Case 2: Working with High School Subject Teacher}

In November 2002, another request was made for MILU's assistance to high school students. On this occasion, the Grade 11 English Literature teacher, a recent graduate of UWI, requested a Library orientation tour for her students from a neighbouring high school, Mona High. The teacher wanted to encourage her students to achieve a higher standard of work by exposing them to their future goal, attendance at UWI. The Library saw this as a means of acquainting students with information literacy competencies. The opportunity was used, therefore, not only to give a tour but also to introduce students to the OPAC as a tool for finding resources in the Library. Many of these students had never had an opportunity to access an online catalogue. The tour allowed them to explore resources in their subject field.

\section{Case 3. Reaching Caribbean High Schools by Distance Education}

The University Distance Education Centre (UWIDEC) is the Department that co-ordinates all distance teaching of UWI. In March 2003, a request was made of MILU to present a session "When researching a topic: Who[m] can I trust? Where can I go?" to approximately sixty students in a number of Caribbean territories. This is part of a series by UWIDEC to assist 6th form students preparing for the Advanced Level Examinations. Other topics in the series to be presented by Faculty include "The Language divide" and "The impact of modern communication technologies." These sessions are transmitted via interactive audio-graphic teleconferencing to UWI distance teaching centres all across the Caribbean.

Aware of the challenges to teaching and learning that the distance method presents, we focused on adding variety to our presentation methods. Therefore, in the two-hour session, we employed not only the lecture method via a brief PowerPoint presentation, but also question and answer. In the distance mode, directed discussion is used widely to "promote several types of thinking" including critical and higher order thinking skills. (Muilenburg and Berge, 2002). Constant interaction with and repetition of the concepts was also important in light of the limitations of distance teaching and also because of our lack of knowledge of the audience's prior information competencies. Flexibility allowed for input from students and catered for the inevitable hitches in the technology. Team teaching provided variety.

The IL competencies highlighted were: identifying an information need; locating, evaluating and using effectively a variety of information resources (traditional sources like reference and text books; periodicals - from scholarly to glossy; the Internet; the mass media; interviews, and even the community grapevine). Recognising that students are exposed to misinformation in all aspects of life, evaluation of information was set in a context wider than the merely academic.

Among the limitations of the cases above was the lack of formal evaluation of the sessions. Still, even such one-off events can provide avenues for bridging the gap between high school and university. The following are suggestions for developing such opportunities.

\section{Suggestions for Future Programmes}

Based on our experiences as Instruction Librarians, the results of the survey among schools and the above IL ventures, we believe that collaboration between UWI and Jamaican high schools for the benefit of our common clientele is possible. In fact, there already exist pockets of activity that may be expanded and exploited.

- Research Day tours could be used as formal avenues for introducing and emphasising IL competencies to high school students. The material could be presented in an interesting and fun way along with tours of the library's collections in an environment that is non-threatening;

- Presentations to 6th Form students via UWIDEC may be regularised and expanded.

- The availability of the Library's OPAC via the Web could be promoted to 6th Formers. MILU might offer short sessions to school librarians on using the OPAC so that they could better assist their students in identifying relevant material prior to visiting the Library;

- Evolving from requests by subject teachers for high school students to use the UWI Library for research, formal sessions for Grades 11-13 students could be instituted. These could include introduction to basic research skills. 
- MILU could design, along with teacher-librarians, summer workshops on IL skills for high school students. This would introduce students to the tools/environment many of them are shortly to use.

- The Hampton experience might be expanded to offer IL sessions in select high schools as staffing allows.

- UWI Library Information packages could be sent to high schools.

- A video of the skit "Information Literate Student" could be developed and made available to high school libraries, along with other teaching material.

- MILU could work in collaboration with the Schools Section of LIAJA to design and conduct additional sessions for school librarians.

- The University Library should lobby the Ministry of Education in Jamaica to develop a comprehensive Information Literacy curriculum for high schools. MILU may then collaborate with organisations like LIAJA to develop a structured curriculum for information literacy skills at the secondary level. The skills content of this syllabus could be linked to that identified as necessary at the tertiary level.

\section{Conclusion}

The major contribution of the UWI Library's in the proposed collaboration would be to increase the exposure of students to IL, especially during summer workshops. However, the other, larger problems are outside the control of both parties - problems of school policy, absence of a single, national IL syllabus for high schools, non-integration of IL within the curriculum, and heavy workloads of teacher-librarians. The solution to these will require intervention by the Ministry of Education. But conditions in the environment, particularly the rising need for IL competence throughout the society, must, sooner rather than later, force a response.

\section{Notes}

1 The University of the West Indies (UWI) is an autonomous regional institution supported by and serving 15 different Caribbean countries. Founded in 1948 at the Mona Campus, Jamaica, the University has campuses in Trinidad and Barbados. The St. Augustine campus in Trinidad was started in 1960 and the Cave Hill campus in Barbados in 1963. UWI also serves the Caribbean region through Distance Centres in non-campus territories. University enrolment for $2000 / 2001$ was 23,925 .

2 Over $70 \%$ of respondents stated they used a variety of information sources for assignments; knew how to use a library to find information, what plagiarism is, how to analyse an essay topic and to write a bibliography. However we suspect that, because of the leading questions, these percentages are inflated.

3 The IL programme replaced the Library's Bibliographic Instruction programme, started in 1985, the focus of which was stated then as teaching students "how to organize and conduct a library search as well as how to select and use appropriate reference works. "(E. Brown, personal communication, May 17, 1985.) Bibliographic instruction was given in a module of a University Course, "Use of English."

4 The use of the skit has been described in: George, Verna and Kerr, Paulette (2002, June). Parties for partnership: getting faculty aboard an information literacy initiative. Paper presented at the 32nd Annual Conference of the Association of Caribbean University, Research, and Institutional Libraries, Ocho Rios, Jamaica.

5 Schools were selected from a list, "Selected feeder schools to UWI Mona", supplied by the University of the West Indies Mona Admissions, March 2003. The survey also included some recommended upgraded secondary schools.

6 This is not unique to Jamaica. See: De Jager and Nassimbeni, 2002, p.170.

7 Jackson, Katherine. (1999). How do I read? In Critical reading. Retrieved November 2, 2002, from Liverpool Hope, Geography for the new undergraduate Web site: http://www.hope.ac/Gnu/Gnubackup/stuhelp/reading.htm 


\section{References}

American Association of School Librarians and Association of College and Research Libraries (2000). Blueprint for collaboration: AASL/ACRL Task Force on the educational role of libraries. Retrieved February 27, 2003, from http://www.ala.org/acrl/blueprint.html

Bishop, Kay \& Larimer, Nancy (1999). Collaboration: Literacy through collaboration. Teacher Librarian, 27(2), 15-20. Retrieved February 27, 2003 from Wilson SelectPlus database.

Cahoy, Ellysa. (2002). Will your students be ready for college? Connecting K-12 and college standards for information literacy. Knowledge Quest 30 (4), 12-15. Retrieved February 24, 2003 from OCLC FirstSearch database.

De Jager, Karin \&Nassimbeni, Mary (2002). Institutionalizing information literacy in tertiary education: lessons learned from South African programs. Library Trends, 51 (2),141-261.

Dickinson, Dennis W.(1981). Library literacy: Who? When? Where? Library Journal, 106 (8), 853-855.

Donham, Jean (1999). Collaboration in the media center: Building partnerships for learning. NASSP Bulletin, (March), 20-26.

Goodin, M. Elspeth (1988). The transferability of library research skills from high school to college (Doctoral dissertation, Rutgers The State University of New Jersey, 1987) UMI 8803480.

Goodin, M. Elspeth (1991) The transferability of library research skills from high school to college. School Library Media Quarterly, 20 (1), 33-42.

Information literacy competency standards for higher education. (2000) Chicago: Association of College and Research Libraries, American Library Association.

Information Literacy Standards for student learning (1998) Chicago: American Library Association.

Jamaica Library Service (2000,Christmas Term) Schools Library Network Region 1Report: Kingston, Jamaica

Kester, Dianne (1994) Secondary school library and information skills: Are they transferred from high school to college? Reference Librarian, 44, 9-17.

Muilenburg, Lin \& Berge, Zane L. (2002) A framework for designing questions for online learning. Retrieved April 3, 2003 from http://www.emoderators.com/moderators/muilenburg.html.

Shelley Robinson, Cherrell (2000, October). Teachers and Information Literacy in Jamaica: A case study. Paper presented at the Commonwealth Library Association (2000) Seminar, Christ Church, New Zealand.

UCLA Graduate School of Education and Information Studies and Pacific Bell Initiatives for 21st Century Literacies. (Producer) (2000) e-literate? [Video Recording] (University of California Regents)

University of the West Indies (1999/2000). Calendar Kingston, Jamaica.

University of the West Indies (1999-2000) Mona Campus Development Plan Kingston, Jamaica.

University of the West Indies (2000) Vice Chancellor's Report to Council (April) Kingston, Jamaica.

Young, Susan A. \& Lynn, Romeo (2002). University and urban school district collaboration: preschoolers and pre-service teachers gain literacy skills. Reading, Research and Instruction 38 (2), 101-14. 


\section{Biographical Note}

Paulette Kerr, B.A., Dip.L.S., M.A. (History), has been a reference librarian at the University of the West Indies, Mona since 1986. She was instrumental in developing a programme for Internet training and a subsequent team of Internet Trainers. In January 2001 she was appointed Coordinator of the Mona Information Literacy Unit (MILU) and given the responsibility to spearhead an IL Programme. A graduate of the ACRL Institute for Information Literacy Immersion, she along with Verna George, in 2002 made IL presentations at the Association of Caribbean University, Research and Institutional Libraries (ACURIL) Conference in Jamaica and at the ALA Conference in Atlanta. Email: verna.george@ uwimona.edu.jm

Verna George, B.Sc. (Zoology); Dip.Ed.; Dip.L.S. (UWI.) is Acting Head of Loan and Reference and the Mona Information Literacy Unit at the University of the West Indies (Mona) Library.

In 2002, she attended the ACRL's IIL Immersion (Track I). With Paulette Kerr, she presented Parties for partnership: Getting faculty aboard an IL initiative at the 32nd Annual Conference of the Association of Caribbean University Research and Institutional Libraries; and, Partnership in the making: The easy task of getting faculty on board an IL initiative at the International Poster Session, ALA Conference (2002). Her poems have been published in The Caribbean Writer, Pathways, and The Arts. Email: paulette.kerr@uwimona.edu.jm

\section{Appendix A:}

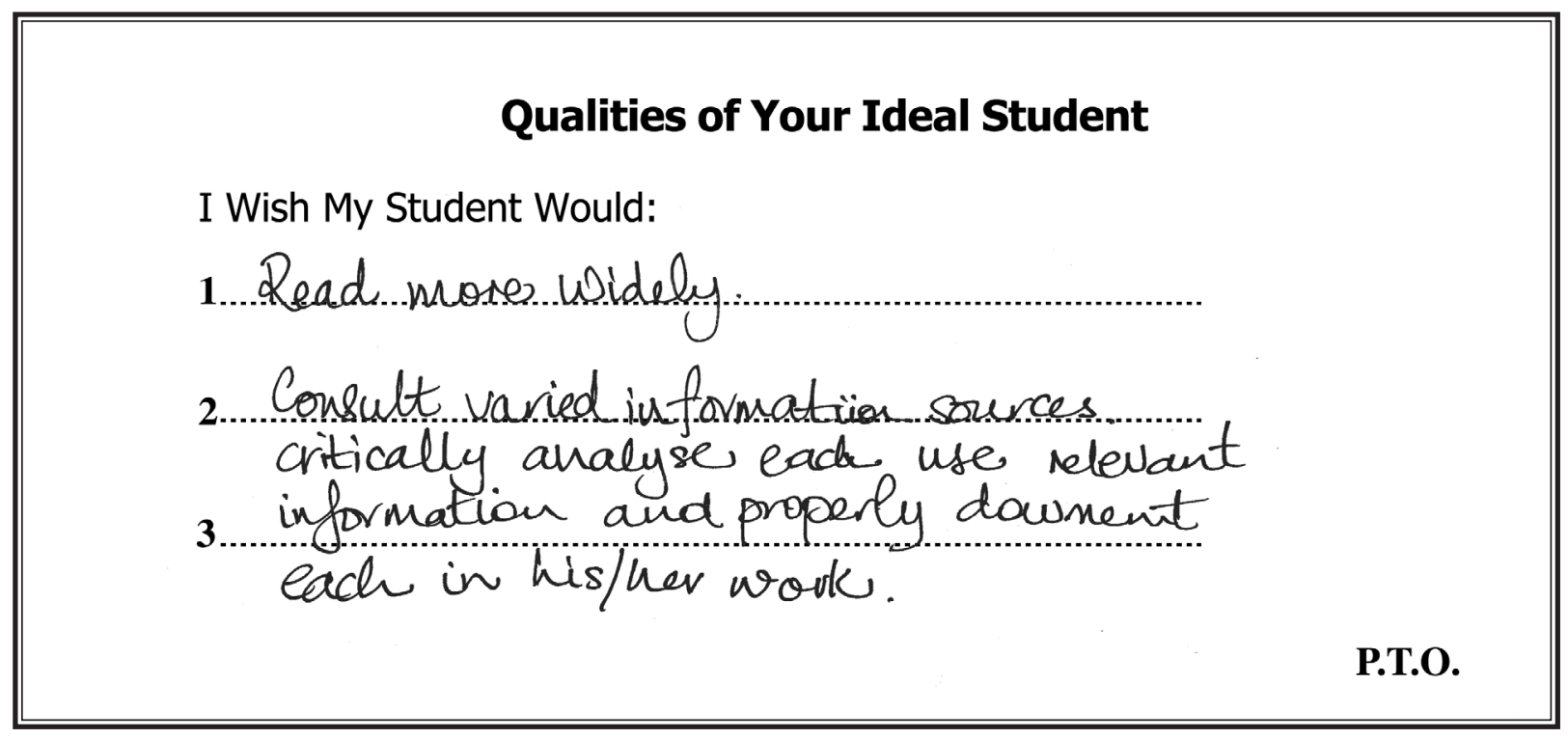

\section{Your Concerns About Your Students}

I Wish My Student Would:Not:

Depend on my knowledge to supply the content of their research. 2.... Use ouly old and outdated sources for
Their research.

3.... Detest neading, resear ching and analysing. 
Appendix B:

\section{"Your Library \& You" Session}

Semester 12002

\section{LIBRARY ACTIVITY}

You may fill in the response below using either a pen or pencil)

FACULTY

HALL

Please answer the following questions in the spaces provided:

1. I feel apprehensive about doing my first UWI class assignment. Yes [ ] No [ ]

2. I know how to use a Library to help me find information. $\quad$ Yes [ ] No [ ]

3. When I do my assignments I usually use information from a variety of sources, eg. encyclopedias, Internet, newspapers.

Yes [ ] No [ ]

4. I know how to analyze my topic before writing an essay.

Yes [ ] No [ ]

5. I know how to search a card catalogue in a library,

Yes [ ] No [ ]

6. I know how to use a computerized catalogue.

Yes [ ] No [ ]

7. I know what plagiarism is.

Yes [ ] No [ ]

8. I know how to write a bibliography.

Yes [ ] No [ ]

9. I have used a search engine to find information on the Internet

10. The search engines I have used are:

11. I have used a library before. 